
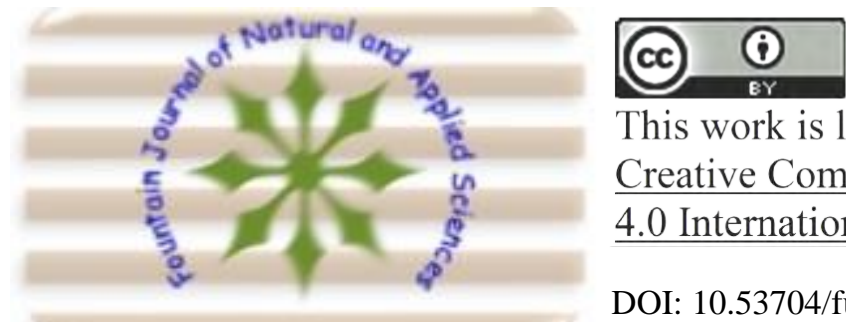

This work is licensed under Creative Commons Attribution 4.0 International License.

DOI: 10.53704/fujnas.v9i1.291

A publication of College of Natural and Applied Sciences, Fountain University, Osogbo, Nigeria. Journal homepage: www.fountainjournals.com ISSN: 2354-337X(Online),2350-1863(Print)

\title{
Comparison of Solid and Solvent - Based Syntheses, Characterization and Antioxidant Property of Metal Complexes of Sodium Diclofenac
}

\author{
${ }^{* 1}$ Osunniran, W. A., ${ }^{1}$ Ayipo, Y. O, ${ }^{1}$ Adeyemo, M. A., ${ }^{1}$ Bale A. T., ${ }^{2}$ Obaleye, J. A. \\ ${ }^{1}$ Department of Chemical, Geological and Physical Sciences, Kwara State University, Malete, Ilorin, Nigeria. \\ ${ }^{2}$ Department of Chemistry, University of Ilorin, Ilorin, Kwara State, Nigeria
}

\begin{abstract}
Mechanosynthesis and solvent - based syntheses of transition metals ( $\mathrm{Ni}$, Co and $\mathrm{Zn}$ ) complexes of Sodium diclofenac has been carried out by 1:1 molar ratio of the ligand to metal salts respectively. The synthesis of the metal complexes were confirmed by melting point determination, FT-IR (Fourier Transform Infra-red) and UV-visible spectroscopies. The ligand showed bidentate coordination to the metal ions through carboxylate moiety. Octahedral geometry was proposed for all the metal complexes. The antioxidant property of metal complexes was determined using DPPH (1,1-diphenyl-2picrylhydrazyl) assay with Ascorbic acid as control. The antioxidant evaluation results revealed that the synthesized metal complexes are promising antioxidant agents.
\end{abstract}

Keywords: Mechanosynthesis; DPPH; Carboxylate moiety; antioxidant evaluation

\section{Introduction}

Mechanochemistry can be seen as an interface between chemistry and mechanical engineering. Mechanochemistry is radically different from the traditional solvent-based, thermal or photochemical mechanisms because it eliminates the need for many solvents, although, its mechanisms of transformations are often complex (Hickenboth et al., 2007; Carlier et al., 2013). It involves the synthesis of chemical products by using only mechanical action. For example, grinding and ball milling methods are widely used mechanochemical processes in which mechanical force is used to achieve chemical processing and transformations (Carlier et al., 2011). In recent times, reactions conducted through grinding or milling, rather than solvent mediation, holds great promise for synthetic chemistry. Mechanochemical synthesis is one of the variants of so-called dry technologies, promising to become an economically profitable (due to reduced number of stages) and ecologically clean procedure compared to the traditional processes. It is now emerging as an alternative reaction media to replace solvent-based synthesis since it is environmental-friendly with a substantial good yield, the reactions is rapid, often reaching substantial completion in several minutes compared to hours in organic solvents (Adams \& Jonathan, 2009; Tella et al., 2011; Arise et al., 2017). This has been widely demonstrated in organic chemistry by Hernández \& Friščić (2015),

*Corresponding author: +2348066741425

Email address: wahab.osunniran@kwasu.edu.ng 
in inorganic and coordination chemistry Arise et al., 2017; Jobbágy et al., 2014) especially in the area of metal organic frameworks $\{$ MOFs $\}$ (Bisht et al., 2015). For example, mechanochemical process has been used as an environmentally preferable way to synthesize pharmaceuticallyattractive phenol hydrazones (Oliveira et al., 2014).

In present study, sodium diclofenac (Figure. 1) transition metal (Co, Ni, Zn) complexes have been synthesized and monitored by using melting point, Fourier Transform Infra-red (FTIR) and Electronic spectroscopy. The antioxidant property of the synthesized metal complexes was also investigated.<smiles>N#CC(=O)Cc1ccccc1Nc1c(Cl)cccc1Cl</smiles>

\section{Figure 1: Molecular Structure of Sodium diclofenac (NaD)}

\section{Materials and Methods Materials}

The ligand, Sodium diclofenac (NaD), DPPH and Ascorbic acid were commercially obtained and used without further purification. Hydrated metal salts used for complexation $\left(\mathrm{NiCl}_{2} \cdot 6 \mathrm{H}_{2} \mathrm{O}\right.$, $\mathrm{CoCl}_{2} \cdot 6 \mathrm{H}_{2} \mathrm{O}$ and $\left.\mathrm{Zn}\left(\mathrm{NO}_{3}\right)_{2} \cdot 6 \mathrm{H}_{2} \mathrm{O}\right)$ were obtained from British Drug House Chemical Limited Co. Poole England.

\section{Instrumentations}

Melting points were determined using MPA100 OptiMelt Automated Melting Point system. The FTIR spectra of both the ligand and the metal complexes were recorded on Thermos Scientific Nicolet i5 Spectrophotometer in the range of 4000 $\mathrm{cm}^{-1}-500 \mathrm{~cm}^{-1}$ using $\mathrm{KBr}$. Solution electronic absorption spectra of the ligand and complexes were ran in the range of $180-400 \mathrm{~nm}$ and 180-1100 $\mathrm{nm}$ respectively on Jenway $6405 \mathrm{Uv} / \mathrm{vis}$.

\section{Solid state synthesis of NaD-metal complexes}

Sodium diclofenac, $\mathrm{NaD}$ ( $1 \mathrm{mmol}, 0.3181 \mathrm{~g}$ ) and each of corresponding metal salts $\mathrm{NiCl}_{2} \cdot 6 \mathrm{H}_{2} \mathrm{O}$ (1 mmol, $0.2377 \mathrm{~g})$; $\mathrm{Zn}\left(\mathrm{NO}_{3}\right)_{2} \cdot 6 \mathrm{H} 2 \mathrm{O}(1 \mathrm{mmol}$, $0.2975 \mathrm{~g}) ; \mathrm{CoCl}_{2} \cdot 6 \mathrm{H}_{2} \mathrm{O}$ (1 mmol, $0.2379 \mathrm{~g}$ ) were weighed into a previously washed and dried agate mortar. Using mortar and pestle at room temperature, the metal salts and the ligand were ground continuously for $15 \mathrm{~min}$ to a fine paste. The grinding continued for additional 5 minutes until no traces of reactants were left. The powders obtained: Zn (white), Ni and Co ( coloured) were washed with little methanol to remove unreacted starting materials . Fine powders obtained in each case as product were weighed and dried in a dessicator over silica gel.

$$
\begin{array}{cccc}
\mathrm{MX}_{2} \cdot \mathrm{nH}_{2} \mathrm{O} & +\mathrm{NaD} & \frac{\text { Grinding }}{20 \text { minutes }} \\
1 & : & 1 & \mathrm{M}(\mathrm{NaD}) \mathrm{X}_{2}\left(\mathrm{H}_{2} \mathrm{O}\right)_{2} \\
& & \mathrm{X}=\mathrm{Cl}^{-} \text {or } \mathrm{NO}_{3}^{-}
\end{array}
$$

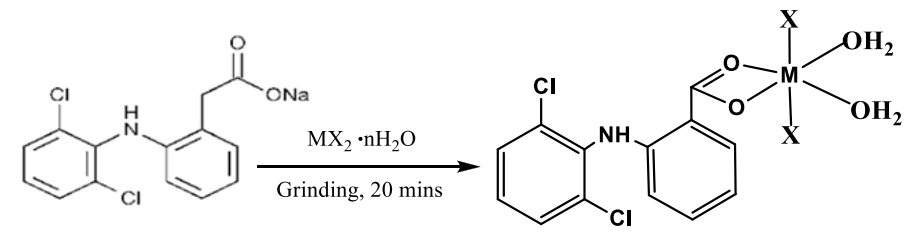

$\mathrm{MX}_{2} \cdot \mathrm{nH}_{2} \mathrm{O}=\mathrm{CoCl}_{2} \cdot 6 \mathrm{H}_{2} \mathrm{O}, \mathrm{NiCl}_{2} \cdot 6 \mathrm{H}_{2} \mathrm{O}, \mathrm{Zn}\left(\mathrm{NO}_{3}\right)_{2} \cdot 6 \mathrm{H}_{2} \mathrm{O}$ $\mathrm{X}=\mathrm{Cl}, \mathrm{NO}_{3}$

\section{Scheme 1: Solid state synthesis of NaD-metal complexes}

$\mathbf{C o}(\mathbf{N a D}) \mathbf{C l}_{2}\left(\mathbf{H}_{2} \mathbf{O}\right)_{2}$ : Yield: $0.5245 \mathrm{~g}(90.4 \%) ; \mathrm{M}$. wt : $461.01 \mathrm{~g} / \mathrm{mol}$; M. pt : $179-182^{\circ} \mathrm{C}$; FTIR (KBR, $\left.\mathrm{cm}^{-1}\right)$ : 3551, 3324, 1694, 1626,1479, 1413, 1322, 1282, $1199,766,741,629,609,529$; UV-Vis(DMSO) $\lambda$, nm: $282,454,688,884$

$\mathbf{N i}(\mathbf{N a D}) \mathbf{C l}_{\mathbf{2}}\left(\mathbf{H}_{\mathbf{2}} \mathbf{O}\right)_{2}$ : Yield: $0.4533 \mathrm{~g}(89.3 \%) ; \mathrm{M}$. wt : $460.77 \mathrm{~g} / \mathrm{mol}$; M. pt : $195^{\circ} \mathrm{C}$; FTIR $\left(\mathrm{KBR}, \mathrm{cm}^{-1}\right): 3422$, 1694, 1621, 1283, 766, 742, 530, 452 ; UV-Vis(DMSO) $\lambda, \mathrm{nm}: 224,296,570,640,753$

$\mathrm{Zn}(\mathbf{N a D})\left(\mathrm{NO}_{3}\right)_{\mathbf{2}}\left(\mathbf{H}_{\mathbf{2}} \mathbf{O}\right)_{2}$ : Yield: $0.5339 \mathrm{~g}(92.6 \%)$; $\mathrm{M}$. wt : $520.95 \mathrm{~g} / \mathrm{mol}$, M. pt : $213^{\circ} \mathrm{C}$; FTIR $\left(\mathrm{KBR}, \mathrm{cm}^{-1}\right)$ : 3751, 3456, 1628, 1509, 1381, 1295, 1250, 1168, 766, 746, 636, 560, 532, 484, 453; UV-Vis(DMSO) $\lambda$, nm: 226,290

\section{Solvent-based synthesis of NaD-metal complexes}

A solution of Sodium Diclofenac $(1 \mathrm{mmol}$, $0.3181 \mathrm{~g})$ in methanol $(10 \mathrm{~mL})$ was drop-wisely added to each of solution of $\mathrm{NiCl}_{2} \cdot 6 \mathrm{H}_{2} \mathrm{O}(1 \mathrm{mmol}$, $0.2377 \mathrm{~g}) ; \mathrm{Zn}\left(\mathrm{NO}_{3}\right)_{2} \cdot 6 \mathrm{H}_{2} \mathrm{O}$ (1 mmol, $0.2975 \mathrm{~g}$ ); $\mathrm{CoCl}_{2} \cdot 6 \mathrm{H}_{2} \mathrm{O}$ (1 mmol, $\left.0.2379 \mathrm{~g}\right)$ in methanol (10 
$\mathrm{mL}$ ). The resulting solutions were refluxed for 1 hour at $70^{\circ} \mathrm{C}$. There were colour changes during the course of refluxing. The precipitates formed after the solution was gently evaporated and the concentrate was allowed to cool for 30 minutes at room temperature. The precipitates were filtered, washed (3 times) with methanol and dried over silica gel in the dessicator.

$$
\begin{gathered}
\mathrm{MX}_{2} \cdot \mathrm{nH}_{2} \mathrm{O}+\underset{1}{\mathrm{NaD}} \stackrel{\mathrm{Reflux}, 1 \mathrm{hr}}{\mathrm{CH}} \underset{3}{\mathrm{OH}} \mathrm{M}(\mathrm{NaD}) \mathrm{X}_{2}\left(\mathrm{H}_{2} \mathrm{O}\right)_{2} \\
\mathrm{X}=\mathrm{Cl}^{-} \text {or } \mathrm{NO}_{3}^{-}
\end{gathered}
$$

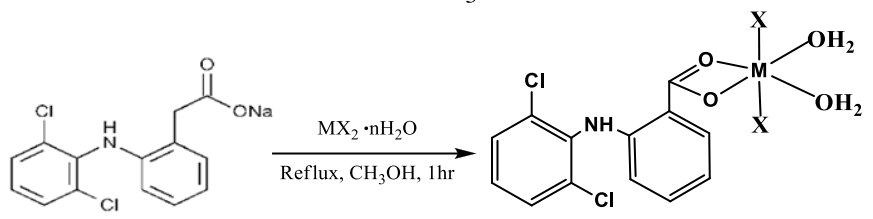

$\mathrm{MX}_{2} \cdot \mathrm{nH}_{2} \mathrm{O}=\mathrm{CoCl}_{2} \cdot 6 \mathrm{H}_{2} \mathrm{O}, \mathrm{NiCl}_{2} \cdot 6 \mathrm{H}_{2} \mathrm{O}, \mathrm{Zn}\left(\mathrm{NO}_{3}\right)_{2} \cdot 6 \mathrm{H}_{2} \mathrm{O}$

$\mathrm{X}=\mathrm{Cl}, \mathrm{NO}_{3}$

\section{Scheme 2: Solvent-based synthesis of NaD- metal complexes}

Co(NaD) $\mathbf{C l}_{2}\left(\mathbf{H}_{2} \mathrm{O}\right)_{2}$ : Yield: $0.2245 \mathrm{~g}(60.7 \%)$; M. wt :461.01 g/mol ; M. pt : $178-180^{\circ} \mathrm{C}$; FTIR $\left(\mathrm{KBR}, \mathrm{cm}^{-}\right.$ $\left.{ }^{1}\right)$ : 3553, 3321, 1695, 1626,1480, 1412, 1322, 1281, 1199, 766, 741, 629, 609, 527; UV-Vis(DMSO) $\lambda$, nm: $282,452,680,887$.

$\mathbf{N i}(\mathbf{N a D}) \mathbf{C l}_{\mathbf{2}}\left(\mathbf{H}_{2} \mathbf{O}\right)_{2}$ : Yield: $0.1533 \mathrm{~g}(58.3 \%)$; M. wt : $460.77 \mathrm{~g} / \mathrm{mol}$; M. pt : $197^{\circ} \mathrm{C}$; FTIR (KBR, $\left.\mathrm{cm}^{-1}\right): 3424$, 1691, 1619, 1281, 766, 742, 530, 450 ; UV-Vis(DMSO) $\lambda$, nm: 224, 295, 570, 642, 751.

$\mathbf{Z n}(\mathbf{N a D})\left(\mathbf{N O}_{3}\right)_{\mathbf{2}}\left(\mathbf{H}_{2} \mathbf{O}\right)_{2}$ : Yield: $0.3327 \mathrm{~g}(75.6 \%)$; $\mathrm{M}$. wt : $520.95 \mathrm{~g} / \mathrm{mol}$, M. pt : $214^{\circ} \mathrm{C}$; FTIR $\left(\mathrm{KBR}, \mathrm{cm}^{-1}\right)$ : 3751, 3454, 1626, 1507, 1381, 1295, 1250, 1166, 766, 746, 636, 560, 531, 484, 450; UV-Vis(DMSO) $\lambda$, nm: 224, 292.

\section{Evaluation of antioxidant activities of Metal (II) Complexes \\ DPPH Antioxidant Assay}

The determination of the free radical scavenging activity of the metal complexes was carried using the DPPH (1,1-diphenyl-2-picrylhydrazyl) assay. Appropriate dilution of the metal complexes $(1 \mathrm{ml})$ was mixed with $3 \mathrm{ml}$ of $60 \mu \mathrm{M}$ acetone, acetic anhydride, DMSO, solution of DPPH radicals; the mixture was left in the dark for $30 \mathrm{~min}$ before the absorbance was measured at $517 \mathrm{~nm}$. The decrease in absorbance of DPPH on addition of test samples relative to the control (ascorbic acid) was used to calculate the percentage inhibition (\% Inhibition) according to the following the equation:

$\%$ Inhibition $=\left[\left(\mathrm{Abs}_{\text {control }}-\mathrm{Abs}_{\text {sample }}\right) \div\right.$ $\left.\mathrm{Abs}_{\text {control }}\right] \times 100$.

\section{Results and Discussion}

The mechanochemical method (Scheme 1) was carried out by manual grinding of Sodium diclofenac and hydrated metal salts of cobalt, nickel and zinc using mortar and pestle. The reaction was done within 20 minutes at room temperature with greater yield as compared to solvent-based (Scheme 2) reaction $\left(120 \mathrm{~min}\right.$ in methanol at $70^{\circ} \mathrm{C}$ ) and 3 days for products to form. The melting point of the metal complexes differ from that of the $\mathrm{NaD}$ $\left(288-290^{\circ} \mathrm{C}\right)$ : this gives an insight into the formation of the coordination compounds. Also, the high purity of the complexes can be predicted from their sharp melting point.

The colours of cobalt (deep purple) and nickel (pale green) complexes are distinctly different from that of the ligand (white). Thus, it can be inferred that the colours displayed by the metal complexes are determined by the metal ions, a possible indication to the formation of coordination compounds.

The metal complexes were completely soluble in polar solvents such as water and methanol and also in DMF and DMSO but, practically insoluble in non-polar solvents indicating that the metal complexes are polar in nature and have tendencies to conduct electricity in solution.

FTIR: The characteristics absorption bands in the spectra of ligands and metal complexes are shown in Table 1. The FT-IR spectra of the complexes synthesized via the two methods are identical, but different from the free ligand (sodium diclofenac, $\mathrm{NaD}$ ), suggesting that both methods produced similar products.

The FTIR spectrum of sodium diclofenac (Figure 2) showed a broad absorption band at 3411 $\mathrm{cm}^{-1}$ which is assignable to the stretching frequency of $\mathrm{OH} / \mathrm{ONa}$ of carboxylic acid group. This band undergone shift in the spectra of the metal complexes (Figure 3 - 5) which is a possible indication that sodium diclofenac coordinated to the metal ions through oxygen atom of hydroxyl 
group of carboxylic acid through replacement of sodium atom by metal ions. This is further supported by the stretching frequency of $\mathrm{C}-\mathrm{O}$ which was observed at $1295 \mathrm{~cm}^{-1}$ in the spectrum of sodium diclofenac and shifted bathochromically in the spectra of metal complexes. This confirms the participation of oxygen in the C-O-M bond (Sharma et al., 2011; Osunniran et al., 2018).

The band observed at $1604 \mathrm{~cm}^{-1}$ and $1471 \mathrm{~cm}^{-1}$ in the spectrum of sodium diclofenac assigned to the asymmetric and symmetric stretching frequency of $\mathrm{C}=\mathrm{O}$ shifted in all the spectra of metal complexes equally supported the proof of coordination of sodium diclofenac to the metal ions through Carboxylate moiety (Obaleye et al., 2014). The absorption bands between $3751 \mathrm{~cm}^{-1}$ and 3550 $\mathrm{cm}^{-1}$ were assigned to stretching frequency of $\mathrm{H}_{2} \mathrm{O}$ molecule coordinated to the metal ions. The strong bands in the range of $1480-1590 \mathrm{~cm}^{-1}$ were assigned to aromatic benzene stretching frequency. The bands found between $450 \mathrm{~cm}^{-1}$ and $532 \mathrm{~cm}^{-1}$ at the fingerprint region of the spectra of the metal complexes is attributed stretching frequencies of $\mathrm{M}-\mathrm{N}, \mathrm{M}-\mathrm{O}$ and $\mathrm{M}-\mathrm{Cl}$. These revealed the metalligand coordination (Obaleye et al., 2014; Osunniran et al., 2018).

Table 1: Selected FT-IR absorption band $\left(\mathrm{cm}^{-1}\right)$ for ligand and Metal Complexes

\begin{tabular}{|c|c|c|c|c|c|}
\hline Ligand/Complexes & $\begin{array}{l}\mathrm{v}(\mathrm{ONa}) / \\
\mathrm{v}(\mathrm{OH})\end{array}$ & $\begin{array}{l}\text { v (COO) } \\
\text { (asy, sym) }\end{array}$ & v (C-O) & $v\left(\mathrm{H}_{2} \mathrm{O}\right)$ & $\mathrm{v}(\mathrm{M}-\mathrm{O} / \mathrm{M}-\mathrm{X})$ \\
\hline NaD & 3411 & 1604,1471 & 1291 & --- & ---- \\
\hline $\begin{array}{l}\mathrm{Co}(\mathrm{NaD}) \mathrm{Cl}_{2}\left(\mathrm{H}_{2} \mathrm{O}\right)_{2} \\
\text { Mechanochemical }\end{array}$ & 3324 & 1654,1587 & 1282 & 3551 & 529 \\
\hline $\begin{array}{l}\mathrm{Co}(\mathrm{NaD}) \mathrm{Cl}_{2}\left(\mathrm{H}_{2} \mathrm{O}\right)_{2} \\
\text { Solvent - based }\end{array}$ & 3326 & 1654,1587 & 1281 & 3550 & 527 \\
\hline $\begin{array}{l}\mathrm{Ni}(\mathrm{NaD}) \mathrm{Cl}_{2}\left(\mathrm{H}_{2} \mathrm{O}\right)_{2} \\
\text { Mechanochemical }\end{array}$ & 3422 & 1621,1588 & 1283 & 3654 & 530,452 \\
\hline $\begin{array}{l}\mathrm{Ni}(\mathrm{NaD}) \mathrm{Cl}_{2}\left(\mathrm{H}_{2} \mathrm{O}\right)_{2} \\
\text { Solvent - based }\end{array}$ & 3421 & 1620,1586 & 1281 & 3653 & 530,450 \\
\hline $\begin{array}{l}\mathrm{Zn}(\mathrm{NaD})\left(\mathrm{NO}_{3}\right)_{2}\left(\mathrm{H}_{2} \mathrm{O}\right)_{2} \\
\text { Mechanochemical }\end{array}$ & 3456 & 1628,1579 & 1250 & 3751 & $532,484,453$ \\
\hline $\begin{array}{l}\mathrm{Zn}(\mathrm{NaD})\left(\mathrm{NO}_{3}\right)_{2}\left(\mathrm{H}_{2} \mathrm{O}\right)_{2} \\
\text { Solvent - based }\end{array}$ & 3458 & 1626,1579 & 1250 & 3751 & $531,484,450$ \\
\hline
\end{tabular}

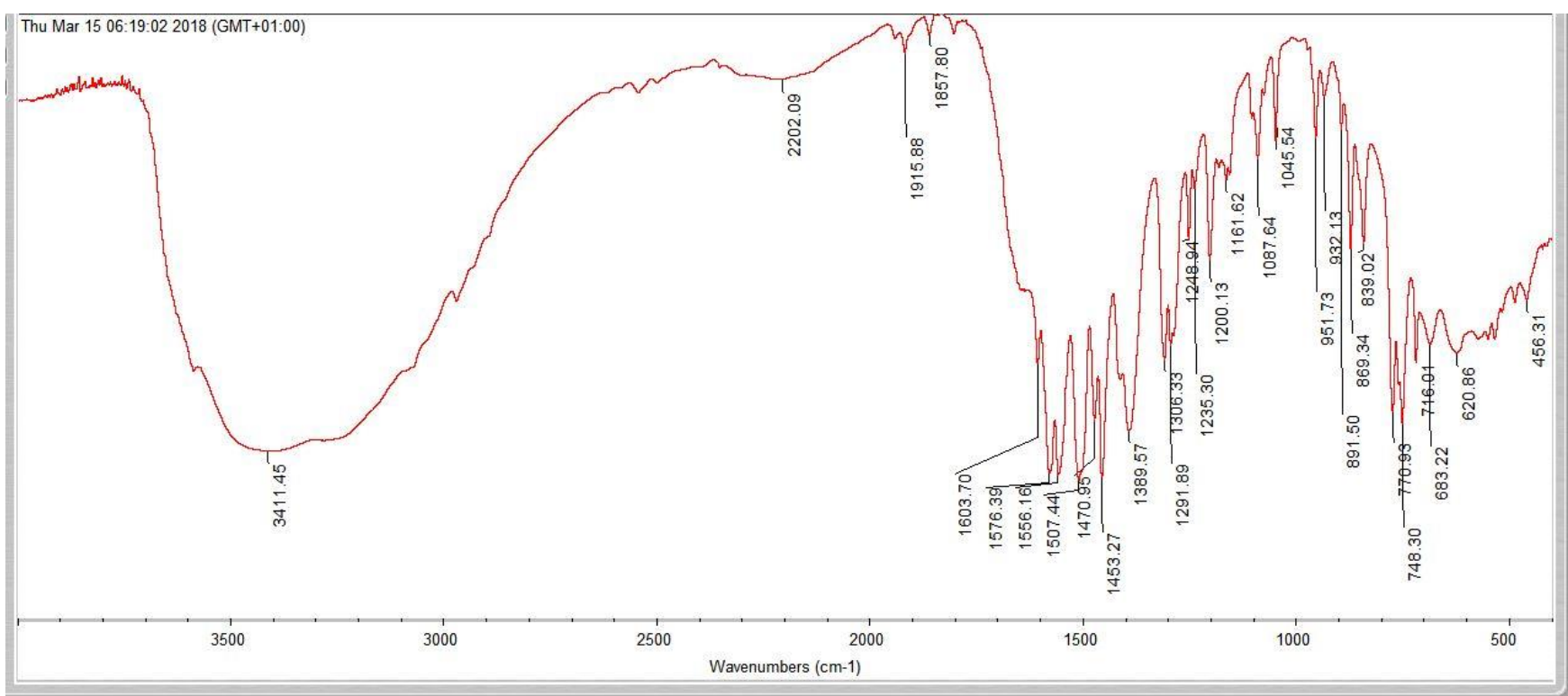

Figure 2: FTIR spectrum of sodium diclfenac (NaD) 
Fountain Journal of Natural and Applied Sciences 2020; 9(1): 11-18

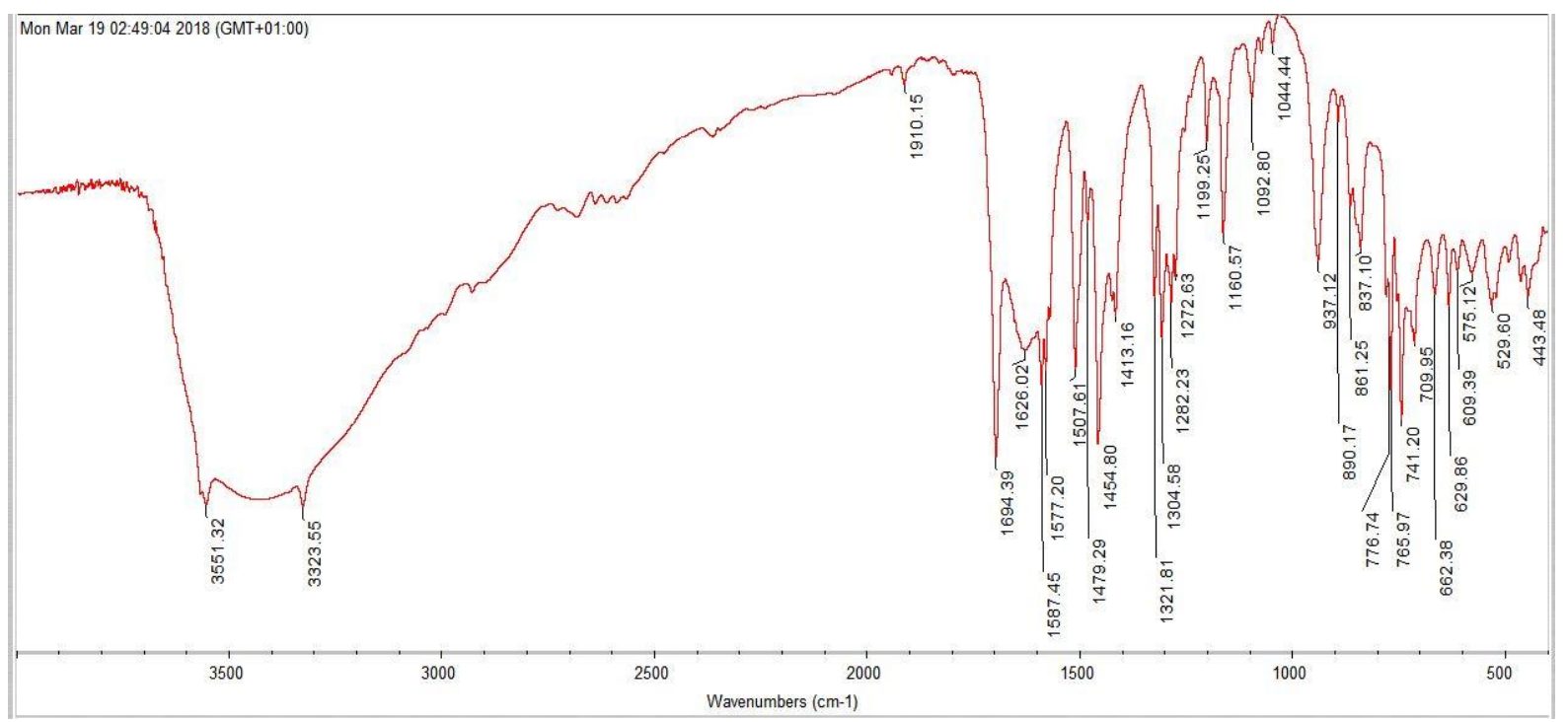

Figure 3: FTIR spectrum of $\mathrm{CoNaDCl}_{2}\left(\mathrm{H}_{2} \mathrm{O}\right)_{2}$

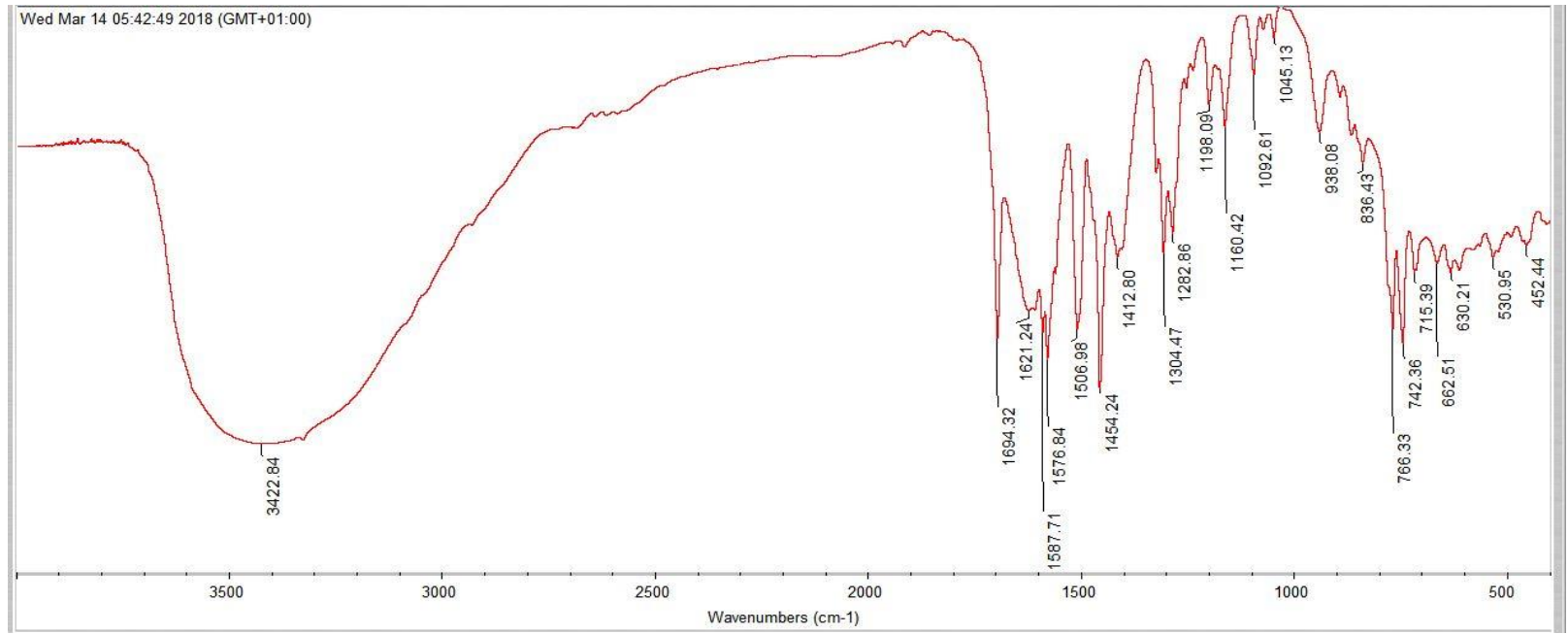

Figure 4: FTIR spectrum of $\mathrm{NiNaDCl}_{2}\left(\mathrm{H}_{2} \mathrm{O}\right)_{2}$

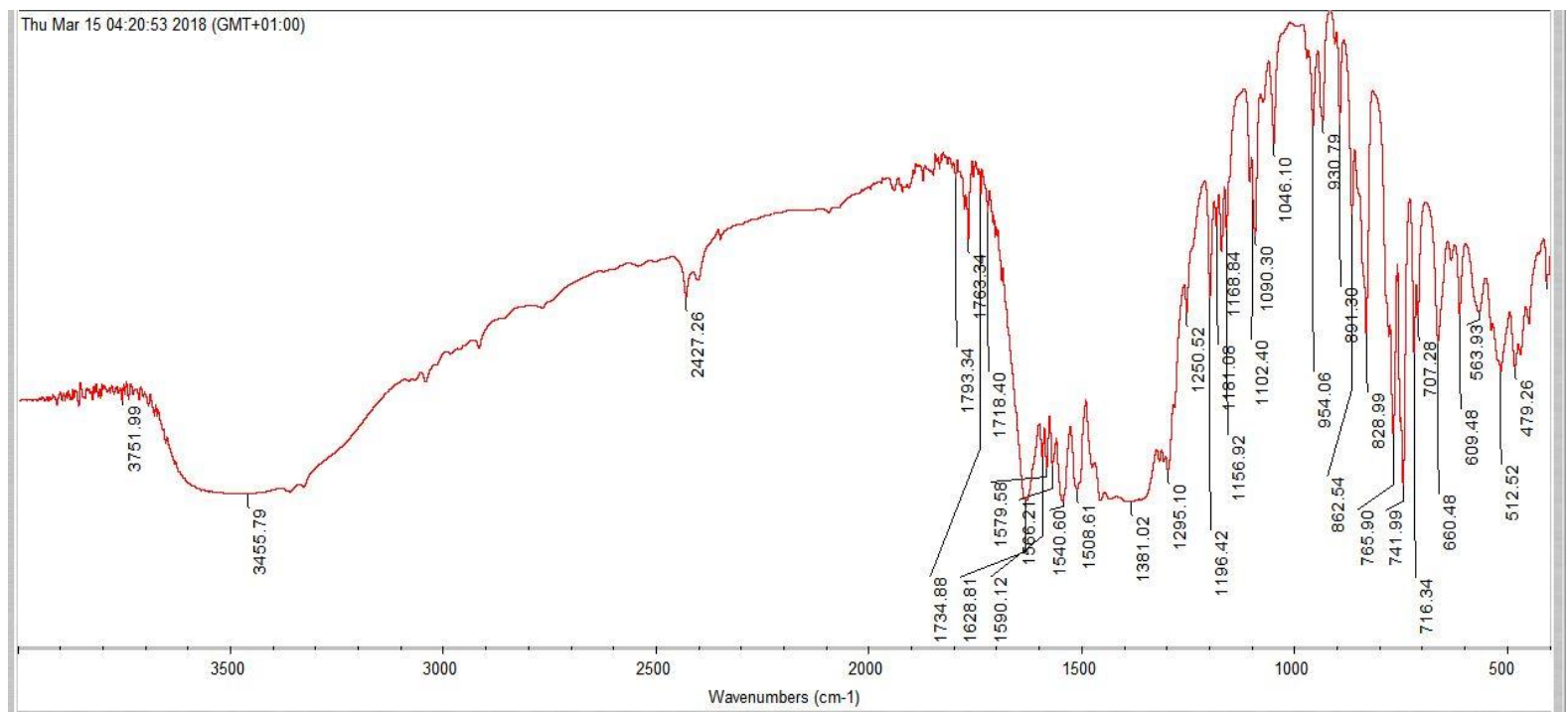

Figure 5: FTIR spectrum of $\mathrm{ZnNaD}\left(\mathrm{NO}_{3}\right)_{2}\left(\mathrm{H}_{2} \mathrm{O}\right)_{2}$ 
Electronic spectra: The electronic spectra data of ligand and metal complexes is contained in Table 2.The electronic spectrum of the free ligand in DMSO showed absorption bands in the UV-region at $196 \mathrm{~nm}$ and $246 \mathrm{~nm}$. These bands are assigned to intra-ligand transition due to $n-\pi *$ transition of the non-bonding electrons present on the oxygen of $(\mathrm{C}=\mathrm{O})$ group. The slight shift and disappearance of the bands in the spectrum of metal complexes relative to the ligand is attributable to coordination (Obaleye et al., 1997). The absorption spectra of Co (II) and $\mathrm{Ni}$ (II) complexes of $\mathrm{NaD}$ showed three bands in the visible region corresponding to the electronic transitions for $\mathrm{d}^{7}$ and $\mathrm{d}^{8}$ ion respectively in an octahedral environment (Najeeb, 2018; Osunniran et al.,2018). Zn(II) compounds do not have additional bands in the visible region since it has $\mathrm{d}^{10}$ configuration and as such there is no $d-d$ transition. However, hypsochromic shifts of the first and second bands points to complex formation (Ali \& Jabali, 2016; Osunniran et al., 2018).

\section{Antioxidant Activity}

The $\mathrm{IC}_{50}$, which stands for the concentration of fraction required for $50 \%$ scavenging activity, was calculated from the dose-inhibition linear regression equation of each complex. The antioxidant property of metal complexes is determined by comparing their $\mathrm{IC}_{50}$ with that of ascorbic acid. The result of antioxidant evaluation of the synthesized metal complexes (Figure $6(\mathrm{a}-\mathrm{d})$ ) revealed that the $\mathrm{IC}_{50}$ of $\mathrm{Co}(\mathrm{NaD}) \mathrm{Cl}_{2}\left(\mathrm{H}_{2} \mathrm{O}\right)_{2}$, $\mathrm{Ni}(\mathrm{NaD})_{2} \mathrm{Cl}_{2}\left(\mathrm{H}_{2} \mathrm{O}\right)_{2}$, and $\mathrm{Zn}(\mathrm{NaD})\left(\mathrm{NO}_{3}\right)_{2}\left(\mathrm{H}_{2} \mathrm{O}\right)_{2}$ is lower than that of ascorbic acid and as such they possess a very good antioxidant property.

\section{Conclusion}

Mechanochemical synthesis of sodium diclofenac - metal complexes represents a comparatively best method of synthesis with no environmental pollution, economically profitable, appreciably good yield and rapid when compared to the solvent-based synthesis that leads to environmental pollution and takes a longer period of time. Coordination compounds of cobalt, nickel and zinc containing sodium diclofenac as ligand have been synthesized by solvent-free and solventbased methods, and characterized by FT-IR, UVvisible techniques and melting point determination. The ligand was found to behave as bidentate ligand coordinated to the metal ions through Carboxylate. Octahedral geometry was proposed for all the metal complexes based on spectroscopic results. Antioxidant evaluation of the metal complexes carried out revealed that the synthesized metal complexes are promising antioxidant agents

Table 2: Electronic Spectra data of the Ligand and the Metal complexes

\begin{tabular}{|c|c|c|c|c|}
\hline & $\begin{array}{l}\lambda_{\max } \\
(\mathbf{n m})\end{array}$ & $\begin{array}{c}\lambda_{\max } \\
\left(\mathrm{cm}^{-1}\right)\end{array}$ & $\begin{array}{c}\lambda_{\max } \\
\operatorname{Energy}\left(\mathrm{KJmol}^{-1}\right)\end{array}$ & Assignment \\
\hline \multirow[t]{2}{*}{$\mathrm{NaD}$} & 196 & 51,020 & 610 & $\mathrm{n}-\pi^{*}$ \\
\hline & 246 & 40,650 & 486 & $\mathrm{n}-\pi^{*}$ \\
\hline \multirow[t]{4}{*}{$\mathrm{Co}(\mathrm{NaD}) \mathrm{Cl}_{2}\left(\mathrm{H}_{2} \mathrm{O}\right)_{2}$} & 282 & 35,461 & 424 & $\mathrm{n}-\pi^{*}$ \\
\hline & 454 & 22,026 & 263 & ${ }^{4} \mathrm{~T}_{1 \mathrm{~g}}(\mathrm{~F}) \longrightarrow{ }^{4} \mathrm{~T}_{1 \mathrm{~g}}(\mathrm{P})$ \\
\hline & 688 & 14,535 & 174 & ${ }^{4} \mathrm{~T}_{1 \mathrm{~g}}(\mathrm{~F}) \longrightarrow{ }^{4} \mathrm{~A}_{2 \mathrm{~g}}(\mathrm{~F})$ \\
\hline & 884 & 11,312 & 135 & ${ }^{4} \mathrm{~T}_{1 \mathrm{~g}}(\mathrm{~F}) \longrightarrow{ }^{4} \mathrm{~T}_{2 \mathrm{~g}}(\mathrm{~F})$ \\
\hline \multirow[t]{5}{*}{$\mathrm{Ni}(\mathrm{NaD}) \mathrm{Cl}_{2}\left(\mathrm{H}_{2} \mathrm{O}\right)_{2}$} & 224 & 44,643 & 534 & $\mathrm{n}-\pi^{*}$ \\
\hline & 296 & 33,784 & 404 & $\mathrm{n}-\pi^{*}$ \\
\hline & 570 & 17,544 & 210 & ${ }^{3} \mathrm{~A}_{2 \mathrm{~g}}(\mathrm{~F}) \longrightarrow{ }^{3} \mathrm{~T}_{1 \mathrm{~g}}(\mathrm{P})$ \\
\hline & 640 & 15,652 & 187 & ${ }^{3} \mathrm{~A}_{2 \mathrm{~g}}(\mathrm{~F}) \longrightarrow{ }^{3} \mathrm{~T}_{1 \mathrm{~g}}(\mathrm{~F})$ \\
\hline & 753 & 13,280 & 159 & ${ }^{3} \mathrm{~A}_{2 \mathrm{~g}}(\mathrm{~F}) \longrightarrow{ }^{3} \mathrm{~T}_{2 \mathrm{~g}}(\mathrm{~F})$ \\
\hline \multirow[t]{2}{*}{$\mathrm{Zn}(\mathrm{NaD})\left(\mathrm{NO}_{3}\right)_{2}\left(\mathrm{H}_{2} \mathrm{O}\right)_{2}$} & 226 & 44,248 & 530 & $\mathrm{n}-\pi^{*}$ \\
\hline & 290 & 34,483 & 412 & $\mathrm{n}-\pi^{*}$ \\
\hline
\end{tabular}




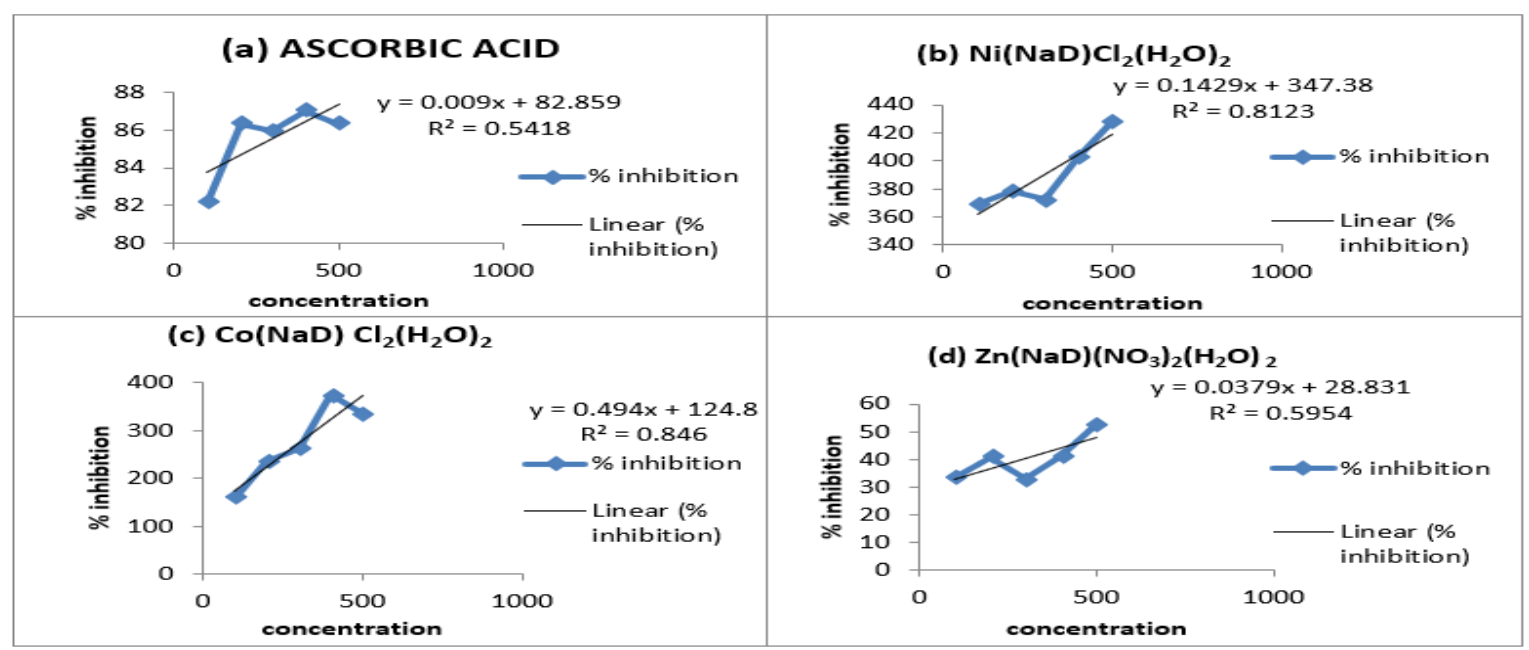

Figure 6: \% inhibition versus concentration curve of (a) Ascorbic acid (b) $\mathrm{Ni}(\mathrm{NaD}) \mathrm{Cl}_{2}\left(\mathrm{H}_{2} \mathrm{O}\right)_{2}$ (c) $\mathrm{Co}(\mathrm{NaD}) \mathrm{Cl}_{2}\left(\mathrm{H}_{2} \mathrm{O}\right)_{2}$ (d) $\mathrm{Zn}(\mathrm{NaD})\left(\mathrm{NO}_{3}\right)_{2}\left(\mathrm{H}_{2} \mathrm{O}\right)_{2}$

Supporting Information: FTIR spectra of ligand and the metal complexes.

\section{References}

Adams, N. S. \& Jonathan, W. S. (2009). The Mechanochemical Synthesis of Pod and Anion Receptors. CrystEngComm, 11, 433-438. DOI: 10.1039/B817067C

Ali, H. A. \& Jabali, B. (2016). Synthesis, characterization and biological activity of novel complexes of zinc(II) diclofenac with nitrogen based ligands. Polyhedron, 107, 97-106. https://doi.org/10.1016/j.poly.2016.01.010

Arise, R. O., Elizabeth, S. N., Farohunbi, S. T., Nafiu, M. O. \& Tella, A. C. (2017). Mechanochemical Synthesis, In vivo Antimalarial and Safety Evaluation of Amodiaquinezinc Complex. Acta facultatis medicae Naissensis, 34(3), 221-233.

Bisht, K. K., Chaudhari, J. \& Suresh, E. (2015). Rapid mechanochemical protocol for isostructural polycatenated coordination polymers [M(BrIP)(BIX)] $(\mathrm{M}=\mathrm{Co}(\mathrm{II}), \mathrm{Zn}(\mathrm{II}))$. Polyhedron, 87, 71-78. https://doi.org/10.1016/j.poly.2014.10.029

Carlier, L., Baron, M., Charmayou, A. \& Couarraze, G. (2011). Use of co-grinding as a solvent-free solid state method to synthesize dibenzophenazines. Tetrahedron Letters, 52(36), 4686-4689. https://doi.org/10.1016/j.tetlet.2011.07.003

Carlier, L., Michel, B., Alain, C. \& Guy, C. (2013). Greener Pharmacy using solvent-free synthesis: investigation of the mechanism in the case of dibenzophenazine. Powder Technology, 240, 41-47. Doi:10.1016/j.powtec.2012.07.009

Hernández, J. G. \& Friščić, T. (2015). Metalcatalyzed organic reactions using mechanochemistry. Tetrahedron Letters, 56 (29), 4253-4265.

doi:10.1016/j.tetlet.2015.03.135

Hickenboth, R., Moore, S., White, R., Sottos, N., Baudry, J. \& Wilson, R. (2007). Biasing Reaction Pathways with Mechanical Force. Nature, $446 \quad$ (7134), 423427. doi:10.1038/nature05681

Jobbágy, C., Molnar, M., Baranyai, P. \& Deák, A. (2014). Mechanochemical synthesis of crystalline and amorphous digold(I) helicates exhibiting anion-and-phase switchable luminescence properties. Dalton Transactions., 43

11807-11810.

https://doi.org/10.1039/c4dt01214c

Najeeb, D. A. (2011). Some Transition Metal Complexes with 2-thioacetic acid-5-pyridyl1,3,4-oxadiazol. Journal of Al-Nahrain University Science, 14(3), 35-39.

Obaleye, J. A., Orjiekwe, C. L. \& Edwards, D. A. (1997). Synthesis and characterization of transition metal complexes of (1-cinnamyl) and (1 - benzyl) - 2,4-diaza-1,3-butanedione. 
Bulletin of the Chemical Society of Ethiopia, 11, 11-18.

Obaleye, J. A., Tella, A. C., Osunniran, W. A., Simon, N. \& Omojasola, P. F. (2014). Synthesis, Characterization, Crystal Structure and Antimicrobial Evaluation of a Novel -M-X-M$\mathrm{X}$ - Type Infinite Chain 1D Cu(II) Complex with Eflornithine Hydrochloride Hydrate as Ligand. Journal of Inorganic and Organometallic Polymers and Materials,24(5), 827-83. DOI: https://doi.org/10.1007/s10904-014-0052-x

Oliveira, P. F. M., Baron, M., Chamayou, A., Andre-Barres, C., Guidetti, B. \& Baltas, M. (2014). Solvent-free mechanochemical route for green synthesis of pharmaceutically attractive phenol-hydrazones. RSC Advances., 4(100), 56736-56742. DOI: 10.1039/C4RA10489G

Osunniran, W. A., Obaleye, J. A., Tella, A. C. \& Amolegbe, S. A. (2018). Synthesis, Characterization and in vitro Antibacterial
Studies of Novel Transition Metal (II) Complexes of 2,5-Diamino-2(difluoromethyl)pentanoic Acid Hydrochloride Hydrate. Orbital: The Electronic Journal of Chemistry, $\quad 10 \quad$ (5), 367-380. DOI: http://dx.doi.org/10.17807/orbital.v10i5.962

Sharma, S. S., Ramani, J., Dalwadi, P., Bhalodia, J., Patel, N. K., Patel, D.D. \& Patel, R. (2011). New ternary transition metal complexes of 2-\{[2aminophenyl) imino]methyl $\}$ phenol and metformin : Synthesis, characterization and antimicrobial activity. E-Journal of Chemistry, 8(1):361-367. DOI: 10.1155/2011/723491

Tella, A. C., Eke, U. B., Issac, A. \& Christianah, A. (2011). Mechanically-Induced Solvent-less synthesis of Cobalt and Nickel Complexes of cimetidine Drug. Orbital - The Electronic Journal of Chemistry, 3(2), 94-103. 